\title{
Kemampuan Mahasiswa Pendidikan Kimia dalam Menganalisis Ayat-ayat Kauniyah yang berasal dari Al-Quran dan As-Sunnah sebagai Petunjuk Pengembangan Kimia Berbasis Wahyu
}

Firmansyah, R. Arizal ${ }^{1}$

\begin{abstract}
ABSTRAK
Kemampuan mahasiswa Pendidikan Kimia dalam menganalisis Ayat-ayat Kauniyah yang berasal dari Al-Quran dan As-Sunnah sebagai petunjuk pengembangan riset kimia berbasis wahyu telah dilakukan. Al-Quran dan As-Sunnah merupakan sumber hukum agama dan sains bagi Muslim sehingga dikatakan bahwa dalam Islam tidak terjadi dikotomi antara agama dan sains, justru integrasi agama dan sains. Ayat-ayat Kauniyah dalam Al-Quran dan As-Sunnah dapat dijadikan sumber gagasan sebagai petunjuk pengembangan riset kimia berbasis wahyu. Pada mata kuliah Keterpaduan IPTEK dan Islam di Fakultas Ilmu Tarbiyah dan Keguruan UIN Walisongo, mahasiswa dilatih menggali gagasan riset kimia dari ayat-ayat Kauniyah dalam Al-Quran dan As-Sunnah menjadi satu makalah ilmiah. Kemampuan mahasiswa Pendidikan kimia secara keseluruhan dalam menganalisis Ayat-ayat Kauniyah ini cukup baik yang dapat diketahui dari menganalisis makalah yang telah disusun secara mandiri, lembar refleksi, dan wawancara.
\end{abstract}

Kata Kunci: Ayat-ayat kauniyah, pengembangan riset kimia berbasis wahyu.

\section{PENDAHULUAN}

Sekularisasi ilmu atau dikotomi antara ilmu agama dan sains (selain agama seperti ilmu fisika, kimia, biologi, sosiologi) berasal dari peradaban barat. Peradaban barat yang maju seperti saat ini, telah melalui tahapan revolusi ilmiah yang dikenal zaman renaisans. Sebelum memasuki tahapan revolusi ilmiah, kehidupan masyarakat barat didominasi oleh aturanaturan gereja yang ketat. Mereka dilarang mengembangkan potensi akal yang bersifat penyelidikan terhadap agama. Jika terdapat pemikiran yang bertentangan dengan aturan gereja, akan mendapatkan hukuman yang berat (Husaini, 2005). Memasuki zaman renaisans pada abad ke-16, dominasi gereja mulai berkurang. Sejak dicetuskannya pernyataan bahwa aku berpikir maka aku ada (cogito ergo sum) oleh René Descartes, maka tolok ukur kebenaran sekaligus sumber ilmu pengetahuan bukan lagi dari ajaran gereja (agama) melainkan rasio dan pancaindera (empirisme). Paham empirisme ini terus berkembang hingga zaman modern atau pencerahan (Husaini et.al., 2013). Berarti pada zaman pencerahan, dikotomi agama dan sains terlihat jelas. Ruang lingkup sains hanya dibatasi pada

\footnotetext{
${ }^{1}$ Pendidikan Kimia pada Fakultas Ilmu Tarbiyah dan Keguruan UIN Walisongo Semarang, Indonesia. E-mail: firmansyaharizal@yahoo.com
} 
objek fisik saja, dapat teramati, terulang, terukur, teruji, teramalkan. Dikotomi ilmu ini berlanjut hingga muncul paham atau pemikiran ateisme atau bebas nilai.

Pada bidang sains, ateisme yang terkenal adalah konsep asal mula makhluk hidup. Menurut Charles Darwin sebagai pencetus ide bahwa asal mula makhluk hidup dari satu nenek moyang yang sama. Jika didapatkan makhluk hidup yang berbeda-beda, maka perbedaan tersebut disebabkan bukan hasil dari ciptaan Tuhan, melainkan hasil dari seleksi atau kondisi alam (Darwin, 1958).

Berdasarkan kajian keilmuan dalam Islam, dikotomi agama dan sains tidak akan pernah ada, justru yang ada adalah sains terintegrasi dalam agama, walaupun tidak semua prinsipprinsip sains dijelaskan secara detail dalam agama. Integrasi sains dalam agama, dapat ditelaah dari adanya kaidah deduktif dan induktif (Nor, 2003). Kaidah deduktif dalam Islam dapat diketahui dari wahyu pertama, Allah menegaskan bahwa sumber ilmu itu berasal dariNya. Allah mengajarkan manusia apa yang semula belum diketahuinya (QS. Al-Baqarah: 31, 239; Ar-Rahman: 1-4). Hal ini berarti semua yang berasal dari Allah, baik berupa ayat-ayat Al-Quran maupun sunnah adalah ilmu yang bermanfaat bagi manusia. Kaidah induktif dalam Islam dapat diketahui dari ayat Al-Quran lainnya yang mengajak manusia merenungi fenomena alam, psikologi dan sejarah (QS. Al-Baqarah: 164; Yusuf: 111). Adanya kaidah deduktif dan induktif ini menunjukkan bahwa kajian keilmuan dalam Islam mencakup aspek keagamaan dalam Al-Quran maupun Sunnah dan fenomena alam atau sains (Nor, 2003).

Pengkajian sains dalam Islam atau lebih dikenal ayat-ayat kauniyah baik yang terdapat dalam Al-Quran maupun As-sunnah belum banyak dilakukan, sementara ini hanya sebatas pencocokan temuan-temuan sains modern (barat) dengan dalil dalil Al-Quran atau As-Sunnah (dalil naqli). Pola kajian yang demikian dikenal dengan istilah Islamisasi Sains atau Ayatisasi Sains. Pola pengkajian lainnya adalah berusaha mencari hikmah di balik ajaran Islam dengan pendekatan ilmiah yang kemudian dikenal dengan istilah Saintifikasi Islam (Purwanto, 2012).

Kedua pola kajian di atas tidak salah tetapi perlu kajian lainnya yaitu kajian yang berusaha mengembangkan riset sains berdasar pada ayat-ayat kauniyah dalam Al-Quran dan As-Sunnah. Maksudnya, berbagai fenomena alam yang tercantum dalam Al-Quran dan AsSunnah (ayat-ayat Kauniyah) baik secara eksplisit maupun implisit hendaknya digunakan sebagai gagasan atau inspirasi dilakukannya suatu riset. Riset yang dikembangkan melalui pola kajian yang demikian tidak banyak dilakukan. Padahal masih banyak Ayat-ayat Kauniyah dalam Al-Quran dan As-Sunnah yang dapat dijadikan sebagai sumber inspirasi atau gagasan dalam riset. Ayat-ayat Kauniyah dalam Al-Quran telah berhasil diklasifikasikan 
oleh Purwanto (2012) menjadi 800 ayat. Meskipun tidak semua fenomena alam terekam dalam Al-Quran, tetapi paling tidak fenomena alam yang tercantum dalam Al-Quran merupakan inspirasi untuk dikembangkan lebih lanjut.

Contoh ayat kauniyah dalam Al-Quran diantara 800 ayat tersebut adalah QS. An-Nahl: 69. Pada ayat ini jelas memberikan informasi bahwa cairan yang keluar dari perut lebah (madu) berfungsi sebagai obat. Telaah lebih lanjut, penyakit apa yang dapat disembuhkan dengan madu, senyawa apa yang menyebabkan warna madu berbeda, apakah ada hubungan antara warna pada madu dengan kemampuannya sebagai obat, berdasar struktur senyawa dalam madu, struktur apa yang menyebabkan madu berfungsi sebagai obat tertentu. Selain obat, pada ayat yang sama, informasi lainnya yang dapat dijadikan gagasan dalam riset adalah bagaimana mekanisme Lebah mencari sumber makanan, senyawa apa yang mampu menimbulkan ketertarikan Lebah untuk dapat menemukan sumber makanan tersebut, bagaimana cara Lebah menginformasikan "berita" tentang sumber makanan ke Lebah lainnya dalam satu koloni, senyawa apa yang menyebabkan "berita" tentang sumber makanan tersampaikan ke Lebah lainnya tersebut, bagaimana elusidasi struktur senyawa tersebut dan bagaimana mensintesisnya. Dengan demikian, banyak gagasan yang dapat diperoleh dalam satu ayat Al-Quran, sehingga tidak ada kekhawatiran tidak adanya sumber inspirasi dalam riset. Sumber inspirasi lainnya dapat ditemukan dalam As-Sunnah seperti pada sabda Nabi tentang keutamaan jinten hitam (Habbatus Sauda') sebagai obat segala penyakit dan masih banyak lagi ayat-ayat Kauniyah dalam Al-Quran dan As-Sunnah yang dapat berfungsi sebagai sumber gagasan yang selanjutnya diimplementasikan dalam bentuk riset (Ali dan Blunden, 2003).

Tergalinya ayat-ayat Kauniyah dalam Al-Quran dan As-Sunnah sebagaimana diuaraikan di atas agar dapat terlaksana, maka perlu kemampuan menganalisa ayat-ayat tersebut. Menganalisa ayat-ayat Kauniyah ini perlu motivasi dan pembiasaan meskipun analisa ayat atau teks dalam Al-Quran dan As-Sunnah membutuhkan ilmu bahasa arab yang dipadukan dengan sains. Perpaduan dua ilmu ini telah diimplementasikan di IAIN Walisongo pada tingkat kurikulum meskipun masih belum semua kurikulum berbasis pada integrasi Islam-Sains. Tetapi paling tidak telah dimulai pada satu mata kuliah yaitu Keterpaduan IPTEK dan Islam. Mata kuliah ini terdapat pada jurusan Tadris Fisika, Biologi, dan Kimia. Konten dan arah kajian keilmuan mata kuliah ini disesuaikan dengan jurusan masing-masing. Misalnya keterpaduan IPTEK dan Islam pada jurusan Tadris Fisika, konten dan arah 
kajiannya tentang ranah Fisika. Begitu juga dengan jurusan Tadris Kimia, konten dan arah kajian keterpaduan IPTEK dan Islam lebih banyak pada ranah Kimia.

Pola atau desain pembelajaran mata kuliah Keterpaduan IPTEK dan Islam pada jurusan Tadris Kimia terbagi menjadi dua tahap, yaitu orientasi dan penugasan. Tahap orientasi terdiri atas 7 topik materi yaitu pengantar, motivasi belajar sains, Ilmu dalam Pandangan Islam: definisi, klasifikasi, hukum mempelajarinya, Paradigma Interaksi Sains dan Islam: Islamisasi Sains, Saintifikasi Sains, dan Sains Islam, Sains Islam: Sains berbasis Wahyu, Sains Modern vs Sains Islam: interseksi, ontologi, aksiologi, dan epistemology, dan Peranan Pendidikan Kimia dalam Diseminasi Kimia Islam. Setelah mengikuti 7 topik materi tersebut, mahasiswa diarahkan membuat artikel kimia tentang gagasan riset kimia yang bersumber pada Al-Quran dan As-Sunnah. Gagasan riset kimia ini disusun baik secara kelompok maupun individu. Penyusunan artikel ini tentu membutuhkan kemampuan analisa dalam membaca pesan ilmiah dalam ayat-ayat Kauniyah dalam Al-Quran dan As-Sunnah. Kemampuan menganalisa inilah yang akan lebih lanjut diteliti bagaimana tingkat kemampuannya yang tercermin pada makalah yang disusun secara individu.

\section{METODE PENELITIAN}

Data dalam penelitian ini diperoleh dengan metode dokumentasi dengan tahapan sebagai berikut: 1) memberikan orientasi perkuliahan dengan materi pokok terdiri dari motivasi belajar sains, ilmu dalam pandangan Islam, paradigma interaksi sains dan Islam, sains Islam (sains berbasis wahyu), sains modern vs sains Islam (interseksi, ontologi, aksiologi, dan epistemologi), peranan Pendidikan Kimia dalam diseminasi kimia berbasis wahyu. Tahap ini berlangsung 15 kali pertemuan. 2) memberikan tugas individu membuat makalah gagasan riset kimia yang berbasis pada ayat-ayat Kauniyah dalam Al-Quran atau As-Sunnah. 3) monitoring pelaksanaan membuat makalah melalui kegiatan pelaporan dan bimbingan atau konsultasi. 4) analisa makalah gagasan riset kimia yang telah disusun oleh mahasiswa secara kuantitatif. Format penilaian makalah gagasan riset kimia berbasis wahyu dapat dilihat pada Tabel 1.

Tabel 1. Format Instrumen Penilaian Makalah Gagasan Riset Kimia Berbasis Wahyu

\begin{tabular}{|c|c|c|c|c|c|c|}
\hline \multirow[b]{2}{*}{ NO } & \multirow{2}{*}{$\begin{array}{c}\text { ASPEK } \\
\text { YANG } \\
\text { DINILAI }\end{array}$} & \multicolumn{5}{|c|}{ SKOR PENILAIAN } \\
\hline & & 5 & 4 & 3 & 2 & 1 \\
\hline 1. & $\begin{array}{l}\text { Ketepatan menentukan } \\
\text { ayat/ hadits Nabi }\end{array}$ & & & & & \\
\hline
\end{tabular}




\begin{tabular}{|c|l|l|l|l|l|l|}
\hline 2. & $\begin{array}{l}\text { Bobot masalah yang } \\
\text { akan diselesaikan }\end{array}$ & & & & & \\
\hline 3. & $\begin{array}{l}\text { Kesesuaian referensi } \\
\text { pada sub.bab Kajian } \\
\text { Riset Sebelumnya }\end{array}$ & & & & & \\
\hline 4. & $\begin{array}{l}\text { Nilai inovatif gagasan } \\
\text { baru }\end{array}$ & & & & & \\
\hline 5. & Sumber munculnya ide & & & & & \\
\hline 6. & $\begin{array}{l}\text { Telaah kata dalam Al- } \\
\text { Quran/ Hadits } \\
\text { menggunakan kaidah } \\
\text { bahasa arab }\end{array}$ & & & & & \\
\hline
\end{tabular}

Keterangan:

Skor 5: Sangat baik/ sangat tepat/ sangat sesuai

Skor 4: Baik/ tepat/ sesuai

Skor 3: Cukup

Skor 2: Kurang baik/ kurang tepat/ kurang sesuai

Skor 1: Sangat kurang baik/ sangat kurang tepat/ sangat kurangsesuai

Analisis data dilakukan untuk mengolah data yang diperoleh di lapangan sehingga diperoleh data yang memuat jawaban atas permasalahan yang dirumuskan. Kemampuan mahasiswa Tadris Kimia dalam menganalisis ayat-ayat Kauniyah analisis Analisis data dalam penelitian ini dilakukan ke dalam bentuk data ordinal terhadap masing-masing aspek yang dinilai dari makalah.

Analisis data dalam penelitian ini mencakup 6 aspek, yaitu (1) ketepatan menentukan ayat/ hadits nabi/ atsar; (2) Bobot masalah yang akan diselesaikan; (3) Kesesuaian referensi pada sub. bahasan kajian riset sebelumnya; (4) Nilai inovatif gagasan baru yang dibuat; (5) Munculnya ide; telaah kata dalam al-quran/ hadist menggunakan kaidah bahasa arab.

Setiap makalah yang telah disusun oleh mahasiswa Tadris Kimia semester genap 20132014 diberi skor berdasarkan rating scale (1-5) di setiap aspeknya sebagaimana pada tabel 3.1. Selanjutnya perolehan skor setiap mahasiswa dijumlah dari ke-enam aspek tersebut. Setelah semua data skor setiap mahasiswa diinput, maka ditentukan skor rata-rata yang selanjutnya dianalisis bagaimana makalah seluruh mahasiswa Tadris Kimia semester genap 2013-2014 apakah sangat baik atau baik atau cukup atau kurang atau sangat kurang berdasarkan kriteria pada Tabel 2.

Tabel 2. Kriteria Penilaian Ideal

\begin{tabular}{|c|r|c|}
\hline No & Rentang Skor & Kategori \\
\hline 1. & $\mathrm{X}>\mathrm{Mi}+1,5 \mathrm{SBi}$ & Sangat Baik \\
\hline 2. & $\mathrm{Mi}+0,5 \mathrm{SBi}<\mathrm{X} \leq \mathrm{Mi}+$ & $\mathrm{B}$ \\
\hline 3. & $\mathrm{Mi}-0,5 \mathrm{SBi}<\mathrm{X} \leq \mathrm{Mi}+$ & Cukup \\
\hline 4. & $\mathrm{Mi}-1,5 \mathrm{SBi}<\mathrm{X} \leq \mathrm{Mi}+-$ & Kurang \\
\hline 5. & $\mathrm{X} \leq \mathrm{Mi}-1,5 \mathrm{SBi}$ & Sangat \\
\hline
\end{tabular}


Keterangan:

X : Skor rata-rata

Mi : Rata-rata ideal

: $1 / 2($ skor maksimal ideal + skor minimal ideal $)$

SBi : Simpangan Baku

: 1/6 (skor maksimal ideal - skor minimal ideal)

Skor maksimal ideal $\quad=\sum$ butir $\mathrm{x}$ skor ertinggi

Skor minimal ideal $\quad=\sum$ butir $\mathrm{x}$ skor terendah

Persentase penilaian makalah mahasiswa Tadris Kimia dihitung dengan menggunakan rumus:

$$
\begin{aligned}
\text { Persentase penilaian } & =\frac{\text { Skor rerata }}{\text { Skor Maksimal }} \\
\text { Skor } &
\end{aligned}
$$

Hasil persentase kriteria penilaian dapat dilihat pada tabel 3 berikut :

\begin{tabular}{|c|c|}
\hline Rata-rata Nilai Kelas & Kategori \\
\hline $80 \%<x \leq 100 \%$ & Sangat baik \\
\hline $67 \%<x \leq 80 \%$ & Baik \\
\hline $53 \%<x \leq 67 \%$ & Cukup \\
\hline $40 \%<x \leq 53 \%$ & Jelek \\
\hline$x<40 \%$ & Sangat Jelek \\
\hline
\end{tabular}

Tabel 3. Kategori Persentase Penilaian

Analisis terhadap setiap aspek di setiap mahasiswa dilakukan dengan cara yang sama dengan analisis terhadap kualitas makalah mahasiswa secara keseluruhan sebagaimana di atas.

\section{HASIL DAN PEMBAHASAN}

Penentuan tingkat kemampuan mahasiswa Tadris Kimia semester genap 2013-2014 dalam menganalisa ayat-ayat Kauniyah yang berasal dari Al-Quran dan As-Sunnah dapat diketahui melalui kualitas makalah gagasan riset kimia berbasis wahyu yang telah disusunnya. Penentuan kualitas makalah ini didasarkan pada asumsi standar ideal (kurva normal), yaitu membandingkan dengan skor ideal. Kriteria penilaian ideal kualitas makalah gagasan riset kimia berbasis wahyu dapat dilihat pada tabel 4 .

Tabel 4. Kriteria Penilaian Ideal Kualitas Makalah

\begin{tabular}{|r|c|c|}
\hline No & Rentang Skor & Kategori \\
\hline 1. & $X>24$ & Sangat Baik \\
\hline 2. & $20<X \leq 24$ & Baik \\
\hline
\end{tabular}




\begin{tabular}{|r|c|c|}
\hline 3. & $16<\mathrm{X} \leq 20$ & Cukup \\
\hline 4. & $12<\mathrm{X} \leq 16$ & Kurang \\
\hline 5. & $\mathrm{X} \leq 12$ & Sangat Kurang \\
\hline
\end{tabular}

Berdasarakan analisis data penilaian terhadap kualitas makalah mahasiswa didapatkan bahwa skor total adalah $490(\mathrm{~N}=27)$, sehingga didapatkan skor rata-rata kualitas makalah adalah 18,15 . Skor rata-rata sebesar 18,15 jika disesuaikan dalam tabel kriteria penilaian ideal maka kualitas makalah mahasiswa Tadris Kimia berada pada rentang skor $16<\mathrm{X} \leq 20$ dengan kategori cukup. Persentase penilaian kualitas makalah mencapai 60,5\% dengan kategori cukup baik.

Hasil secara keseluruhan bahwa tingkat kemampuan mahasiswa Tadris Kimia semester genap 2013-2014 dalam menganalisa ayat-ayat Kauniyah yang berasal dari Al-Quran dan AsSunnah adalah cukup baik. Tetapi rincian lebih detail terhadap kemampuan mahasiswa ini dapat diketahui melalui analisis di setiap aspek makalah yang dinilai yaitu (1) Ketepatan menentukan ayat/ hadits nabi; (2) Bobot masalah yang akan diselesaikan; (3) Kesesuaian referensi pada sub. bahasan kajian riset sebelumnya; (4) Nilai inovatif gagasan baru yang dibuat; (5) Munculnya ide; (6) Telaah kata dalam al-quran/ hadist menggunakan kaidah bahasa arab.

Aspek ketepatan dalam menentukan ayat/ hadits nabi diperoleh skor rata-rata 4,33 $(\mathrm{N}=27)$ sehingga jika disesuaikan dengan tabel 5. Kriteria Ideal Aspek (1) diperoleh kategori sangat baik dengan persentase sebesar 86,66 \% (sangat baik).

Tabel 5. Kriteria Penilaian Ideal Aspek (1)

\begin{tabular}{|c|c|c|}
\hline No & Rentang Skor & Kategori \\
\hline 1. & $\mathrm{X}>4,005$ & Sangat Baik \\
\hline 2. & $3,335<\mathrm{X} \leq 4,005$ & Baik \\
\hline 3. & $2,665<\mathrm{X} \leq 3,335$ & Cukup \\
\hline 4. & $1,995<\mathrm{X} \leq 2,665$ & Kurang \\
\hline 5. & $\mathrm{X} \leq 1,995$ & Sangat Kurang \\
\hline
\end{tabular}

Aspek bobot masalah yang akan diselesaikan diperoleh skor rata-rata 3,592 (N=27) sehingga jika disesuaikan dengan tabel 6. Kriteria Ideal Aspek (2) diperoleh kategori baik dengan persentase sebesar 71,84\% (baik).

Tabel 6. Kriteria Penilaian Ideal Aspek (2)

\begin{tabular}{|c|c|c|}
\hline No & Rentang Skor & Kategori \\
\hline 1. & $\mathrm{X}>4,005$ & Sangat Baik \\
\hline 2. & $3,335<\mathrm{X} \leq 4,005$ & Baik \\
\hline
\end{tabular}




\begin{tabular}{|c|c|c|}
\hline 3. & $2,665<\mathrm{X} \leq 3,335$ & Cukup \\
\hline 4. & $1,995<\mathrm{X} \leq 2,665$ & Kurang \\
\hline 5. & $\mathrm{X} \leq 1,995$ & Sangat Kurang \\
\hline
\end{tabular}

Aspek kesesuaian referensi pada sub. bahasan kajian riset sebelumnya diperoleh skor ratarata 3,815 ( $\mathrm{N}=27)$ sehingga jika disesuaikan dengan tabel 7. Kriteria Ideal Aspek (3) diperoleh kategori baik dengan persentase sebesar 76,29\% (baik).

Tabel 7. Kriteria Penilaian Ideal Aspek (3)

\begin{tabular}{|c|c|c|}
\hline No & Rentang Skor & Kategori \\
\hline 1. & $X>4,005$ & Sangat Baik \\
\hline 2. & $3,335<X \leq 4,005$ & Baik \\
\hline 3. & $2,665<X \leq 3,335$ & Cukup \\
\hline 4. & $1,995<X \leq 2,665$ & Kurang \\
\hline 5. & $X \leq 1,995$ & Sangat Kurang \\
\hline
\end{tabular}

Aspek nilai inovatif gagasan baru yang dibuat diperoleh skor rata-rata 3,629 (N=27) sehingga jika disesuaikan dengan tabel 8. Kriteria Ideal Aspek (4) diperoleh kategori baik dengan persentase sebesar 72,59\% (baik).

Tabel 8. Kriteria Penilaian Ideal Aspek (4)

\begin{tabular}{|c|c|c|}
\hline No & Rentang Skor & Kategori \\
\hline 1. & $X>4,005$ & Sangat Baik \\
\hline 2. & $3,335<X \leq 4,005$ & Baik \\
\hline 3. & $2,665<X \leq 3,335$ & Cukup \\
\hline 4. & $1,995<X \leq 2,665$ & Kurang \\
\hline 5. & $X \leq 1,995$ & Sangat Kurang \\
\hline
\end{tabular}

Aspek munculnya ide diperoleh skor rata-rata 1,78 ( $\mathrm{N}=27)$ sehingga jika disesuaikan dengan tabel 9. Kriteria Ideal Aspek (5) diperoleh kategori sangat kurang dengan persentase sebesar $35,60 \%$ (sangat jelek).

Tabel 9. Kriteria Penilaian Ideal Aspek (5)

\begin{tabular}{|c|c|c|}
\hline No & Rentang Skor & Kategori \\
\hline 1. & $X>4,005$ & Sangat Baik \\
\hline 2. & $3,335<X \leq 4,005$ & Baik \\
\hline 3. & $2,665<X \leq 3,335$ & Cukup \\
\hline 4. & $1,995<X \leq 2,665$ & Kurang \\
\hline 5. & $X \leq 1,995$ & Sangat Kurang \\
\hline
\end{tabular}

Aspek telaah kata dalam al-quran/ hadist menggunakan kaidah bahasa arab diperoleh skor rata-rata 1 $(\mathrm{N}=27)$ sehingga jika disesuaikan dengan tabel 4.7. Kriteria Ideal Aspek (6) diperoleh kategori sangat kurang dengan persentase sebesar $20 \%$ (sangat jelek). 
Tabel 4.7. Kriteria Penilaian Ideal Aspek (6)

\begin{tabular}{|c|c|c|}
\hline No & Rentang Skor & Kategori \\
\hline 1. & $X>4,005$ & Sangat Baik \\
\hline 2. & $3,335<X \leq 4,005$ & Baik \\
\hline 3. & $2,665<X \leq 3,335$ & Cukup \\
\hline 4. & $1,995<X \leq 2,665$ & Kurang \\
\hline 5. & $X \leq 1,995$ & Sangat Kurang \\
\hline
\end{tabular}

Kualitas makalah gagasan riset kimia berbasis wahyu yang telah disusun oleh mahasiswa Tadris Kimia semester genap tahun akademik 2013-2014 di setiap aspek yang dinilai jika disajikan dalam bentuk grafik dapat dilihat pada Gambar 4.1 sebagai berikut.

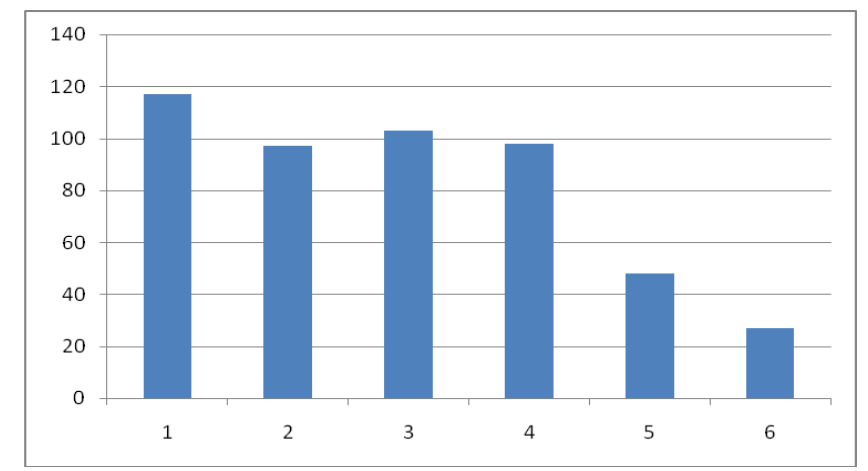

Gambar 2. Grafik Kualitas Makalah Gagasan Riset Kimia Berbasis Wahyu yang telah disusun oleh Mahasiswa Tadris Kimia Semester Genap Tahun Akademik 2013-2014. Sumbu X: Aspek yang dinilai sedangkan sumbu Y: Skor Total di setiap Aspek yang dinilai.

Berdasarkan Gambar 4.1 di atas, terlihat bahwa jumlah skor tertinggi terletak pada aspek (1) yaitu ketepatan dalam menentukan ayat/ hadits nabi/ atsar sedangkan jumlah skor terendah terletak pada aspek (6) yaitu telaah kata dalam al-quran/ hadist menggunakan kaidah bahasa arab.

Kualitas makalah gagasan riset kimia berbasis wahyu yang telah disusun oleh mahasiswa semester genap tahun akademik 2013-2014 secara keseluruhan berdasar hasil analisis ternyata cukup baik. Hal ini menunjukkan bahwa kemampuan mahasiswa dalam menganalisis ayat-ayat Kauniyah dalam Al-Quran dan As-Sunnah cukup baik. Walaupun jika dianalisis lebih lanjut terhadap keenam aspek yang dinilai, kemampuan mahasiswa dalam menganalisis bervariasi.

Berdasar Gambar 2, terlihat jelas bahwa skor rata-rata atau persentase aspek (1) paling tinggi. Hal ini berarti kualitas makalah gagasan riset kimia yang berbasis wahyu atau kemampuan mahasiswa Tadris Kimia dalam menganalisis ayat-ayat Kauniyah dan AsSunnah paling baik terletak pada aspek (1). Hal ini disebabkan mahasiswa sangat terbantukan dengan adanya index Al-Quran online pada alamat http://www.quranterjemah.com. Website ini memberikan fasilitas pencarian kata dalam Al-Quran baik menggunakan bahasa arab maupun bahasa indonesia. Mahasiswa hanya mengetikkan kata kunci dengan pilihan bahasa yang ada, maka website ini akan memberikan hasil berupa berapa kali kata tersebut 
disebutkan dalam Al-Quran, terletak di surat dan ayat berapa dalam Al-Quran. Tetapi pada aspek (5) kemampuan mahasiswa dalam menganalisis sangat kurang atau sangat jelek. Hal ini berarti mayoritas mahasiswa Tadris Kimia ketika membuat judul makalah tidak mampu atau kesulitan menggali ide dari ayat-ayat Kauniyah Al-Quran atau Hadist dan memang terbukti berdasar hasil wawancara selama proses konsultasi dan bimbingan serta dokumen lembar refleksi, hanya 7 mahasiswa saja diantara 27 mahasiswa yang menggali ide dari ayatayat Kauniyah Al-Quran atau Hadist, selebihnya ide judul atau gagasan baru makalah berasal dari keyakinan di masyarakat, browsing internet dan pengalaman hidup pribadi masingmasing. Ayat-ayat Al-Quran atau Hadist yang dijadikan sumber gagasan diantaranya kata yaqthiin dalam QS. Ash-Shafaat ayat 146:

“Dan Kami tumbuhkan untuk Dia sebatang pohon dari jenis labu”.

Kata Thalhin dalam QS. Al-Waaqi'ah ayat 27-3:1

"dan golongan kanan, alangkah bahagianya golongan kanan itu. Berada di antara pohon bidara yang tak berduri, dan pohon pisang yang bersusun-susun (buahnya), dan naungan yang terbentang luas, dan air yang tercurah,".

Kata yang lebih general yaitu maa fis samaawaati wa maa fil ardhi dalam QS. AlJaatsiyah:13

"Dan Dia telah menundukkan untukmu apa yang di langit dan apa yang di bumi semuanya, (sebagai rahmat) daripada-Nya. Sesungguhnya pada yang demikian itu benar-benar terdapat tanda-tanda (kekuasaan Allah) bagi kaum yang berfikir"

Kata Habbatus sauda' dalam Hadist Nabi:

'Hendaknya kalian mengkonsumsi Habbatus sauda' (jintan hitam). Karena Habbatus sauda' mengandung obat untuk segala jenis penyakit, kecuali As Saam (kematian).” (HR: Al Bukhari, Muslim, At Tirmidzi, Ahmad dan Ibnu Hibban).

Kata zanjabila dalm QS. Al-Insan:17

"di dalam syurga itu mereka diberi minum segelas (minuman) yang campurannya adalah jahe."

Aspek lainnya yang kualitasnya sangat rendah dapat dilihat pada aspek (6) yaitu telaah kata dalam al-quran/ hadist menggunakan kaidah bahasa arab. Pada aspek inilah kualiatas makalah paling rendah diantara aspek lainnya. Hal ini menunjukkan bahwa tidak ada satupun mahasiswa Tadris Kimia yang menggunakan kaidah bahasa arab dalam menelaah kata atau ayat Kauniyah baik dalam Al-Quran maupun Hadist. Hal ini disebabkan karena mayoritas mahasiswa Tadris Kimia semester genap tahun akademik 2013-2014 sangat rendah kemampuan gramatikal bahasa arabnya walaupun mereka mayoritas alumni Madrasah 
Aliyah. Padahal kemampuan bahasa arab sangat penting dalam menelaah ayat-ayat kauniyah dalam Al-Quran dan As-Sunnah karena dengan paham kaidah gramatikal bahasa arab akan mengerti variasi perubahan kata yang memiliki kedalaman makna tersendiri dalam ayat-ayat Al-Quran dan As-Sunnah.

Berbeda dengan aspek (5) dan (6), aspek (2), (3) dan (4) memberikan informasi bahwa kemampuan mahasiswa Tadris Kimia dalam menganalisi ayat-ayat Kauniyah dalam AlQuran dan As-Sunnah dapat dikatakan baik. Bobot masalah yang akan diselesaikan pada aspek (2) tergolong baik walaupun terdapat beberapa mahasiswa yang mengangkat masalah dalam makalah sangat baik. Ukuran kualitas masalah dapat diketahui dari seberapa besar dan urgenitas masalah tersebut untuk diselesaikan, misalkan salah satu gagasan atau judul makalah "sediaan asam alfa linolenat dari biji selasih sebagai perangsang perkembangan otak anak”. Biji selasih yang dianggap kurang berarti oleh sebagian masyarakat ternyata berdasar kajian pustaka mampu dijadikan sumber asam alfa linolenat sebagai perangsang perkembangan otak anak.

\section{KESIMPULAN}

Berdasarkan hasil analisis data dan uraian pada pembahasan, maka penelitian ini dapat disimpulkan bahwa kemampuan mahasiswa dalam menganalisis ayat-ayat Kauniyah dalam Al-Quran dan As-Sunnah secara keseluruhan cukup baik dengan perolehan skor rata-rata 18,15 dan persentase $60,5 \%$.

Hasil penelitian ini menyarankan bahwa kemampuan mahasiswa Tadris Kimia khususnya dalam menganalisis ayat-ayat Kauniyah dalam Al-Quran dan As-Sunnah dapat ditingkatkan dengan cara: 1) menambah kemampuan bahasa arab (minimal gramatikal) sehingga mampu mengeksplorasi ayat-ayat Kauniyah dalam Al-Quran dan As-Sunnah menjadi gagasan riset kimia yang berbasis wahyu. Penambahan kemampuan bahasa arab khususnya terhadap mahasiswa Tadris Kimia dapat dilakukan dengan menerapkan strategi pembelajaran bahasa arab aktif yang mampu memberi motivasi belajar mahasiswa dan penambahan jam pembelajaran di luar jam aktif kuliah. 2) meningkatkan penguasaan konsep ilmu kimia terutama kimia dasar, kimia organik, kimia anorganik, dan kimia fisik. 3) meningkatkan tafsir ilmi yaitu upaya memadukan antara kosakata dalam ayat-ayat Kauniyah dalam Al-Quran dan As-Sunnah dengan penjelasan dari sisi sains kimia. 4) mencari formula kurikulum tadris kimia berbasis wahyu. 


\section{DAFTAR PUSTAKA}

Ali, B. H., dan Blunden, 2003, Pharmacological and Toxicological Properties of Nigella sativa, Phytotherapy Research, 17, 299 -305.

Darwin C., 1958, The Origin of Species (New York: New American Library.

Husaini, A., 2005, Wajah Peradaban Barat: dari Hegemoni Kristen ke Dominasi SekularLiberal, Jakarta: Gema Insani Press.

Husiaini, A. et. al., 2013, Filsafat Ilmu: Perspektif Barat dan Islam, Jakarta: Gema Insani Press.

Nor Wan Daud, W.M., 2003, Budaya Ilmu Satu Penjelasan, Singapura: Pustaka Nasional Pte. Ltd.

Mahran J. dan Mubasyir A. A., 2006, Al-Qur'an Bertutur tentang Makanan dan Obatobatan, Yogyakarta: Mitra Pustaka.

Purwanto Agus, 2012, Nalar Ayat-ayat Semesta: Menjadikan Al-Quran basis konstruksi Ilmu Pengetahuan, Bandung; Mizan Pustaka 